\title{
Conceptualizing regional powers' geoeconomic strategies: neo-imperialism, neo-mercantilism, hegemony, and liberal institutionalism
}

\author{
Mikael Wigell ${ }^{1}$
}

Published online: 14 November 2015

(C) The Author(s) 2015. This article is published with open access at Springerlink.com

\begin{abstract}
This article argues that geoeconomics, defined as the geostrategic use of economic power, has become an increasingly important feature of regional powers' strategic behavior. Yet, we still lack analytical tools to identify and compare regional powers' geoeconomic strategies. The article marks a first attempt to develop a typology for differentiating potential geoeconomic strategies that regional powers may pursue in dealing with their corresponding regions. It merges the regional power focus with a geoeconomic perspective, producing the following four ideal-typical strategies: neoimperialism, neo-mercantilism, hegemony, and liberal institutionalism. This new typology serves as a conceptual device for creating analytical differentiation between regional powers and the range of possible geoeconomic strategies pursued by them. The paper discusses ways in which the new typology may contribute to our understanding of regional powers' foreign policy conduct and to the emerging geoeconomic research agenda. While the purpose of the article is not to test any specific hypothesis or to empirically analyze cases, brief case study vignettes will be presented for illustrative purposes, looking particularly at Brazil, the EU, Germany, and Russia.
\end{abstract}

\section{Introduction}

International relations are increasingly shaped by two important and in many ways intertwined developments. Firstly, the resurgence of regional powerhood (see Prys 2012) has been a dominant feature of the post-Cold War era. Regional powers - both "new" and "old"- such as Brazil, Germany, China, India, Japan, Russia, and South Africa, are defining regional relations to an ever greater extent, and in many instances, they have also come to wield more influence at the global level. Secondly, geoeconomics has arguably become an increasingly important aspect of contemporary

Mikael Wigell

mikael.wigell@fiia.fi

1 The Finnish Institute of International Affairs, Kruunuvuorenkatu 4, P.O. Box 400, 00161 Helsinki, Finland 
international relations. The post-Cold War era is characterized not so much by political or ideological rivalry but by economic competition. With the partial exception of Russia, it is also economic - not military-capabilities that underpin the resurgence of regional powers. Indeed, these regional actors are foremost economic powers and the use of this economic power constitutes their most important strategic asset. How they use it is of major importance for their corresponding regional orders and, by extension, for the international order.

Yet, we still lack analytical instruments to identify and compare regional powers' geoeconomic strategies. Extant theories often assume monolithic behavior by regional powers (e.g., Mearsheimer 2001; for a discussion, see also Destradi 2010; Prys 2010). However, even a superficial comparison between, for instance, Germany and Russia, in the way they project power in their neighborhood shows two divergent strategies at work. Regional powers are not monolithic in their strategic outlook; therefore, we need analytical tools that can better identify empirical variation between them and lay the ground for a comparative analysis of regional power strategies. Some scholars have begun to develop such tools, constructing typologies for differentiating ideal-typical strategies that regional powers might pursue in dealing with their neighbors in the region (Destradi 2010; Prys 2010). But no such attempt has yet been made for the geoeconomic strategies of regional powers. Herein lies a gap in the literature. If, indeed, the role of geoeconomics has emerged to rival geopolitics in the strategic thinking of regional powers, as some observers claim, developing better analytical tools for understanding geoeconomic power and its use is imperative.

This article seeks to contribute to this debate by suggesting an ideal-typical taxonomy of potential geoeconomic strategies that regional powers may pursue in dealing with their corresponding regions. It merges the regional power focus with a geoeconomic perspective, producing the following four ideal-typical strategies: neo-imperialism, neo-mercantilism, hegemony, and liberal institutionalism. This new typology serves as a device for creating analytic differentiation between regional powers and the range of possible geoeconomic strategies pursued by them. Such a typology is an important starting point for further theoretical and empirical work. The purpose of this article is therefore not to test any specific hypothesis or to empirically analyze cases, although brief references will be made to illustrative cases. What this article does is merely to develop a conceptual scheme that can be used in subsequent empirical and theoretical research to analyze regional powers' strategies. Importantly, it is the first such attempt from a geoeconomic perspective.

This article first discusses geoeconomics as an analytical perspective. It argues that geoeconomics forms an important part of regional powers' strategic behavior. It then reviews different conceptualizations of geoeconomics and argues for choosing an eclectic approach, whereby these different conceptualizations can be used to create analytic differentiation. Making use of such an approach, the third section creates a typology for differentiating regional powers' geoeconomic strategies. Here, brief case study vignettes will also be presented looking particularly at Brazil, the EU, Germany, and Russia. All four are geoeconomically powerful actors in their corresponding regions. Yet, they clearly employ diametrically different geoeconomic strategies and, 
therefore, serve as ideal-typical illustrative cases. ${ }^{1}$ The paper concludes by discussing ways in which the new typology may contribute to our understanding of regional power foreign policy conduct and to the emerging geoeconomic research agenda.

\section{Regional powers and geoeconomics: an eclectic approach}

As an analytic perspective, geoeconomics usually starts from the premise of the relative decline of military concerns and the rise of economic concerns in relations between states (e.g., Luttwak 1990; Szabo 2015; Zarate 2012). It emphasizes how states primarily compete with each other for economic power. According to Huntington (1993, p. 72), “... in a world in which military conflict between major states is unlikely, economic power will be increasingly important in determining the primacy or subordination of states." By merging geopolitics and economics, the geoeconomic perspective highlights how in the current international system, economic - rather than military-leverage is more consequential in the pursuit of national interests.

The imperatives of geoeconomics are clearly discernable in the foreign policies of regional powers (Baracuhy 2013; Hsiung 2009; Khandekar 2014; Tsygankov 2005; Szabo 2015; see also Hurrell 2006). Regional powers usually apply economic rather than military means when pursuing strategic objectives on the international stage. Not only do they seldom possess the necessary military power to pursue their foreign policy goals through the use of force but also the security challenges that they now encounter also tend to be of an economic nature and therefore less amenable to military solutions (e.g., Brattberg and Hamilton 2014; Mudiam 2007; Wright 2013). While not displacing military security concerns, economic security has thus been elevated on the scale of strategic priorities to a country's national interests (Hsiung 2009; Zarate 2012). As regional powers aim to expand their markets, guarantee their supply lines, and secure their access to finance and cutting-edge technologies, economic security has become a vital component of regional powers' ability to project their power and influence.

So, irrespective of the question whether geoeconomics has actually eclipsed geopolitics as a strategic desideratum in the foreign policies of regional powers - a question which this paper will not address - it seems clear that geoeconomic calculations form part of regional powers' geostrategies. It thus becomes imperative to systematically compare the geoeconomic strategies of regional powers, which calls for developing better analytical tools. This requires a brief analysis of the concept of geoeconomics itself and what possible variations exist in terms of strategic practice.

While no shared definition of the concept of geoeconomics has emerged, it can be broadly understood to revolve around the geostrategic use of economic power. Irrespective of their varying military capabilities, Brazil, Germany, China, India, Japan, Russia, and South Africa are all major economic powers in their respective regions, on which minor neighboring powers are more or less dependent. ${ }^{2}$ Typically, they are the most important trading partners for several other countries within the region, and some of them are clearly the geographic nodes of regional economic

\footnotetext{
${ }^{1}$ This article does not attempt to explain why they employ different strategies, which may have to do with a number of factors ranging from structural to institutional and cultural differences. Here, the purpose is descriptive, using them as cases to illustrate how regional powers' geoeconomic strategy may differ.

${ }^{2}$ For a discussion of what constitutes “economic power," see Kappel (2011).
} 
networks (e.g., Chen and De Lombaerde 2014). They also control significant financial assets that can be deployed beyond their borders. This economic and financial potential provides them with asymmetric economic power that may be leveraged for national advantage (Armijo et al. 2014; Wu and Koh 2014). Regional powers may threaten to cut off smaller neighbors from trade and finance in an effort to coerce them. ${ }^{3}$ Alternatively, they may use positive incentives to affect their behavior. Sometimes, trade and investment ties are so important that they will almost automatically lead to the creation of pro-regional power interest groups and constituencies in neighboring states (Wright 2013). Among geoeconomic observers, there seems to be broad agreement that the sort of asymmetric interdependence that regional economic systems often embody provides regional powers with disproportionate leverage (Kappel 2011). Trading relationships, investment capital, overseas aid, and the leverage stemming from being able to wield influence in global monetary or trade regimes all provide Brazil, Germany, China, India, Japan, and Russia with economic power which they can use to affect the behavior of others. ${ }^{4}$ Yet, observers differ in relation to the question as for what ends economic power is strategically used (political versus economic) and through what sort of strategic frame (competitive versus cooperative) it is employed.

To Luttwak, geoeconomics denoted "the pursuit of adversarial goals with commercial means" (Luttwak quoted in Cable 1995, p. 308) exposing the growing importance of economic over military means in pursuing strategic ends. Such a realist conceptualization of geoeconomics emphasizes how competition for relative power continues to drive state behavior in international relations, albeit using economic as opposed to military means (Luttwak 1990; see also Huntington 1993). Within this realist paradigm, geoeconomics has strong links to geopolitics - economic foreign policy is deployed not only to maximize the country's socioeconomic wellbeing but also to fulfill broader geostrategic goals. These may have to do with improving the country's position in the regional or international hierarchy; gaining prestige or, eventually, after having acquired a sustainable economic basis; improve the country's broader geopolitical potential. The emphasis is thus clearly on the pursuit of relative, political goals.

Yet, one may also envisage a more liberal conceptualization of geoeconomics, in which economic power is used and pursued as an end in itself and not necessarily through a competitive strategic frame. Here, the strategic goals are more purely economic and may be pursued, not as a zero-sum game with the goal of maximizing relative gains but in cooperation with others in the pursuit of common goals (Grevi 2011). Contrary to realists, who argue that states are naturally competitive, liberals take the option of cooperative engagement between states far more seriously. Within such a liberal paradigm, the links to geopolitics are weaker. Economic foreign policy is deployed primarily to ensure a favorable external environment for developing the domestic economy.

There is no reason, a priori, to eschew either perspective, as both strategic uses of economic power seem perfectly plausible. On the one hand, a country's economic potential and its external economic policy instruments may be used for exerting political influence, with the aim of improving the country's geopolitical status (i.e., a

\footnotetext{
${ }^{3}$ According to McKeown (1983:77), "There is...a much more potent and historically relevant weapon of economic 'power' available to the hegemonic state: it can threaten to cut off one nation's access to its rich home market while allowing other nations continued access to that market."

${ }^{4}$ For a seminal analysis of trade as an instrument of foreign policy, see Hirschman (1980). See also McKeown (1983) for a discussion of instruments of economic power.
} 
political end). On the other hand, economic power may also be used for purely economic ends, to preserve or attain a privileged position for the country's economy in the international arena. In either case, economic power is leveraged for national advantage. Whether it is leveraged aggressively as a unilateral act or using a more multilateral approach by cooperatively engaging with other states depends on the strategic frame of the country in question. With a strategic frame, I refer to the particular beliefs, values, and ideas that shape a country's geoeconomic strategy. ${ }^{5}$ Countries may embody realist or more liberal strategic frames through which they conduct their external economic policies. Any typology of regional powers' geoeconomic strategies should therefore incorporate both realist and liberal perspectives, keeping open the possibility of both realist and liberal strategic uses of economic power in practice.

In fact, this sort of theoretical eclecticism serves as a way to create analytical differentiation. By combining both realist and liberal conceptualizations of geoeconomics, we can construct a typology that incorporates possible divergence in strategic behavior without having to exclude any type of behavior ex ante by theoretical fiat. Instead, it can be left open for empirical analysis what type of geoeconomic strategy a certain regional power engages in and comparisons can be made between different cases. Scholars have called for more eclectic international relation research, emphasizing 'the virtues of an 'eclectic combination' of diverse theoretical perspectives in making sense of cases, cautioning against the excessive 'simplifications' required to apply a single theoretical lens to grasp the manifold complexities on the ground" (Sil and Katzenstein 2010, p. 412). The eclectic approach to typology building adopted here seeks to bridge different paradigms and combine them so as to allow for a more diverse and flexible framework of analysis.

\section{Regional powers' geoeconomic strategies: an ideal-typical taxonomy}

Regional power geoeconomic strategy is here referred to as the use of economic leverage by a preponderant regional actor to preserve and realize its interests in the region. ${ }^{6}$ Such a definition does not a priori posit a certain type of strategic behavior to a regional power. Instead, by assuming that regional actors have some degree of freedom of choice with regard to devising strategies, the definition leaves it open to empirical research to find out what type of strategy a certain regional power actually applies. A regional power is therefore simply taken to mean an actor that displays preponderance in relation to most other actors in a region in terms of power capabilities. ${ }^{7}$ No further assumptions are made about their behavior, whether they exercise leadership or fulfill any other roles in their regions. This contrasts with some recent studies on regional

\footnotetext{
${ }^{5}$ For a discussion of "frames," see Barnett (1999). For a broader discussion of strategic culture, see Johnston (1995).

${ }^{6}$ While regional powers may posess varying capabilities for global action so that some of them also can be called "global powers," the focus in this article is on their regional power roles. It may well be that their varying global capabilities affect their chosen (regional) geoeconomic strategy, but that is a question for empirical research and does not form part of the conceptual mission of this article.

${ }^{7}$ While building on Destradi (2010) and Prys (2010), this definition does not foreclose the possibility of a regional multipolarity, i.e., a situation in which more than one regional power exists within a certain region. Britain, France, and Germany have historically often displayed preponderance to most other actors in Europe, without anyone of them being able to exercise regional hegemony. It still makes sense calling them all regional powers on the basis of their preponderant capacities for regional action in relation to other European actors.
} 
powers in which they are "conceived of as states pursuing exclusively benevolent, leading, integrating strategies" (Destradi 2010, p. 907). ${ }^{8}$ For instance, Nolte (2010, p. 893) conceptualizes regional powers as claimers of a "leading" role in the region and constituting a long list of criteria ranging from the provision of collective goods for the region to defining the regional security agenda and being recognized as the leader by other states inside and outside of the region. However, the problem with such an expanded definition of regional power is that it forecloses analysis of issues that may be better to leave open for empirical research.

The model depicted in Fig. 1 develops an ideal-typical taxonomy of possible geoeconomic strategies pursued by regional powers by distinguishing whether the regional power (1) has a competitive or cooperative strategic frame and (2) treats economic power as a means to other strategic aims or as a goal in itself.

As for (1), considering that regional powers have a preponderance of economic power resources vis-à-vis neighboring countries, distinguishing competitive from cooperative strategic frames include observing whether a regional power stands prepared to act unilaterally also when it is clear that it may negatively affect minor neighboring powers. When the goal is to perpetuate economic domination and the cementing of a hierarchical relationship in which neighboring states are made more dependent on the regional power, allowing it to reap national benefits at the expense of mutual benefits, it seems clear that the strategic frame is competitive. Herein, coercive external economic policies may be deployed, such as threatening to cut off market access, commodity supply, or foreign aid in order to pressure a neighboring minor power to acquiesce to a hierarchical, even exploitative, relationship that allows the regional power to write the rules of the game. Alternatively, a regional power may be prepared to act for the achievement of collective goals for a regional grouping, which would clearly indicate a cooperative strategic frame. In this case, the conduct of a regional power may involve acting as the "paymaster," by providing positive incentives for regional institutionalization and committing itself to the common norms and rules of such regional governance structures.

As for (2), it may not always be simple to determine whether economic power is deployed as a means to achieve broader geopolitical aims, e.g., regional political domination, or as a goal in itself, i.e., to accumulate wealth and well-being and reduce economic vulnerability. When a regional power is prepared to invest considerable economic resources in exchange for political influence and alliances, without any clear prospect of gaining economic returns on this investment, economic power is clearly deployed as a means to some other goal, be it to elevate its geopolitical status or cement its leadership in the region, for instance. The way Venezuela under Chavez used its oil rents to gain political influence in Latin America and engage in "soft balancing" against the USA is a case in point (Corrales 2009; Jácome 2011). Russia's preparedness to act as the paymaster for the Eurasian Economic Union, despite the economic benefits for Russia itself being highly questionable, is also an indication of external economic policy being subordinated to broader political goals (Roberts et al. 2014). So, although the means are economic, the underlying motivations are political.

Alternatively, when a regional power is clearly not prepared to assume the costs of regional leadership, but rather uses its economic power to further its own commercial

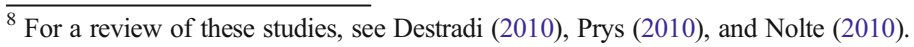




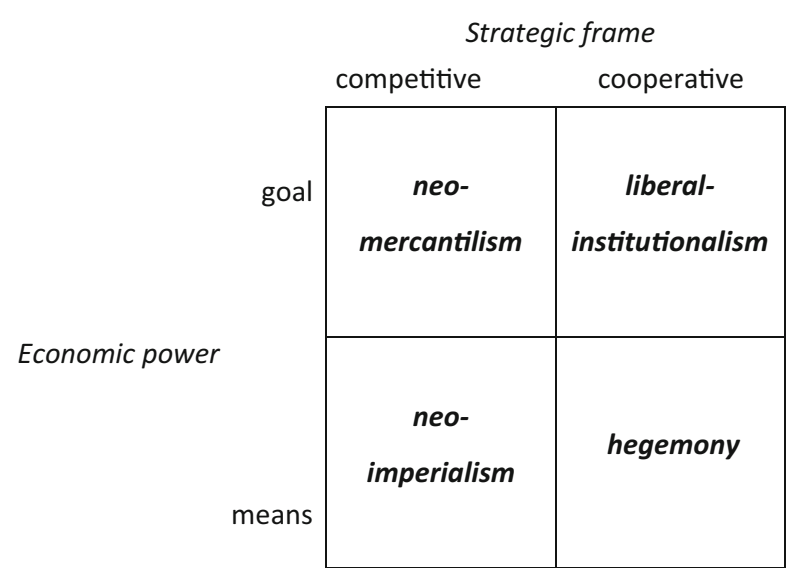

Fig. 1 Regional powers' geoeconomic strategies

interests, it indicates that the driving motivations are narrowly economic rather than more broadly political. For instance, Brazil has often been seen as unwilling to invest in regional leadership. Often characterized as a "geopolitically satisfied country," Brazil has defined its national interests in economic terms, with national economic development therefore being a far more important foreign policy goal than assuming political leadership in the region (Malamud and Rodriquez 2014; Soares de Lima and Hirst 2006). Britain has already for decades pursued a regional policy of promoting its commercial interests in Europe, while showing little interest in broader regional leadership. Its motivations for engaging in EU integration have been economic, and for that end, it has been using its economic leverage within Europe, trying to promote a more economically liberal outlook for the EU, in accordance with Britain's national trade and investment interests (Wall 2008; see also Mayer 2010). Politically, its strategy has more often been one of "escaping the region," so as to eschew any costs involved with regional political activism. As such a "detached regional power" Britain does not actively nourish any broader regional political project but uses its economic power foremost to further its own economic interests in the region.

By combining (1) and (2), Fig. 1 constructs a matrix with the following four idealtypical geoeconomic strategies: neo-imperialism, neo-mercantilism, hegemony, and liberal institutionalism. Both neo-mercantilist and neo-imperialist strategies stem from a competitive strategic frame in which foreign relations are treated as a zero-sum game in which one side's gain is another's relative loss. Both strategies may deploy economic power as aggressive leverage to extract concessions and pressure neighboring countries in a unilateral pursuit of national interest. Yet, they differ as to whether such economic power is seen as a means to pursue other strategic objectives or as a goal in itself above other strategic objectives. In contrast, liberal institutionalist and hegemony strategies are pursued by regional powers with an essentially cooperative strategic frame, in which the role of mutual gains and benefits in interactions with neighboring countries are highlighted. Both strategies refrain from coercion, which is seen as detrimental to the long-term interests of the regional power. The focus is instead on the commonality of gains and the reciprocal flow of benefits, whereby the regional power may also take upon itself the role of the provider of public goods to solve or circumvent the collective 
action problems that may plague the efforts of parties seeking to reap joint gains. Yet, they differ as to whether such economic power is deployed for purely economic ends or merely as means to broader political hegemonic aspirations. A closer look at these strategies together with short glances at some examples of these strategies will help clarify their differences.

Neo-imperialist geoeconomic strategies are essentially deployed by regional powers not only as a way to pursue economic objectives but also to create an "informal" empire in the neighborhood. In contrast to traditional geopolitical strategies, it is not so much concerned with enlarging its territorial control, as with pursuing various forms of economic control, shaping the regional economic structure in such a way that makes weaker states dependent on the regional power. The means employed are economic, but the goal is geopolitical-creating neoimperial relations with weaker neighbors and thus substantially limiting their sovereignty in relation to the regional power's interests. As against the notion of "hegemony," the means employed in the exercise of power in the case of neoimperialism involves economic force, coercion, imposition, and bribery. ${ }^{9}$ Economic force refers to the use of sanctions such as trade embargoes and financial blockades intended to inflict real economic pain and make weaker states acquiesce with the preferences of the regional power. Economic coercion implies making a conditional threat of using such sanctions, altering the calculus of the weaker state and pressuring it to comply. Economic imposition takes place when the asymmetry is so great that the weaker state's position is that of a vassal on which the regional power does not need to use either force or coercion to make the weaker state acquiesce. Bribery refers to prepaid rewards to both private and state actors in neighboring countries in order to make them acquiescent and inflict dependencies. ${ }^{10}$

The way Russia under President Vladimir Putin's reign has conducted its external economic policy would seem to point towards a neo-imperialist strategy par excellence. A central element of this strategy has been the geostrategic use of Russia's energy capacities. These have been seen by Russian policymakers, starting with President Putin himself, as a potent economic means to strengthen Russia's geopolitical position (Cohen 2009; Liuhto 2010; Stulberg 2005). Making neighboring countries dependent on Russia's energy supply and markets has been an important foreign policy goal. While Russia has shown its preparedness to provide certain public goods through the Eurasian Economic Union, ${ }^{11}$ it has hardly escaped anybody in the region that Russia's geoeconomic strategy also involves using coercion and bribery if necessary. Russia has on many occasions threatened to cut energy supplies to neighboring countries and also

\footnotetext{
${ }^{9}$ One may recall the distinction between dominance (i.e., imperialism) and hegemony developed by Hedley Bull (quoted in Hurrell 2013, pp. 55-56): "Dominance is characterized by the habitual use of force by a great power against the lesser states comprising its hinterland and by habitual disregard of the universal norms of interstate behavior that confer rights of sovereignty, equality, and independence upon these states...where a great power exercises hegemony over the lesser powers in a particular area of constellation there is a resort to force, but this is not habitual and uninhibited but occasional and reluctant. The great power prefers to rely upon instruments other than the direct use or threat of force and will employ the latter only in situations of extremity and with a sense that in doing so, it is incurring a political cost."

${ }^{10}$ For a related discussion, see Knorr (1977).

${ }^{11}$ Russia has provided financial assistance to the smaller members of the EEU to help them restructure their economies (Roberts et al. 2014).
} 
used this energy weapon against countries such as Ukraine. It has threatened to cut access to the Russian market for products from neighboring countries such as Moldova in an effort to coerce them to join the Russia-led Eurasian Economic Union instead of the EU's Eastern Partnership (Paul 2013). There are also strong indications of Russia using bribery, especially in Ukraine, to make policymakers in neighboring countries acquiescent to the preferences of Russian economic interests (see, e.g., Grey et al. 2014). The Eurasian Economic Union project, as already mentioned above, is also seen by many analysts as an attempt by Russia to further its broader geostrategic goals by means of external economic policy (Roberts et al. 2014). Russia's strategic use of its economic power thus clearly aims towards broader political goals, rather than just to promote its national commercial interests. The strategic frame of Russian policymakers is also clearly competitive rather than cooperative, emphasizing relative as against absolute gains.

Neo-mercantilist geoeconomic strategies are not foremost deployed to pursue some immediate geopolitical project but to pursue economic power objectives as such. They denote an economy-oriented notion of foreign policy realism that understands the global political economy in terms of a zero-sum competition for the control of markets, technology, and resources. Neo-mercantilist geoeconomic powers are essentially "trading states" (Rosecrance 1986) that define their national interest foremost in economic terms, while applying multilateralism selectively with a close view to national economic security concerns. Maximizing economic power thus forms the bedrock of neo-mercantilist geoeconomic strategies. Contrary to a neo-imperialist strategy, which ultimately seeks political domination through economic means, a neo-mercantilist strategy dictates avoiding costly political commitments or a proactive regional political role, so as to be able to devote maximum attention to national economic development.

In discussing Japan's strategy of economic power maximization, Huntington (1993) identified five main components of that strategy: (1) producer dominance-giving priority to producer interests over consumer interests; (2) industry targeting-developing manufacturing capacities first for the home market and then for export markets, with a particular focus on "strategic, high-technology, high-value added industries" (p. 73); (3) expanding market shares-increasing the market shares of the country's corporations at the expense of profits, so a deliberate strategy of pursuing "relative gains in terms of market shares, rather than absolute gains in terms of profits" (p. 74); (4) import restriction - curbing imports and foreign direct investment; and (5) sustained surplus - accumulating foreign exchange reserves through sustained trade surpluses and by intervention in currency markets. ${ }^{12}$ Scholars have identified these same components in the Chinese strategy of economic power maximization (e.g., Grosse 2014). What all this amounts to is a confrontational approach to international relations. By accumulating wealth, the state seeks to improve the relative position of the country's economy in the international hierarchy so as to enhance the state's autonomy and bargaining power in the international and regional arena.

Like Japan and China, Brazil also provides a case of a neo-mercantilist geoeconomic strategy. A quest for autonomy, economic development, and improving Brazil's relative position in the global economy were the main drivers of its foreign

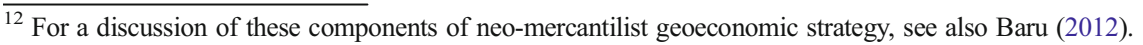


policy already during the Cold War (Hurrell 2013; Soares de Lima and Hirst 2006). Burges (2012) also explains how Brazil follows a largely "distributive strategy" as a negotiator in regional and global fora, contrasting it with an "integrative strategy"; i.e., it views international negotiations mainly as a zero-sum game. The job of the negotiator therefore becomes one of maximizing the share of the pie for Brazil's own, relative benefit. Burges (2012, 2013) also explains how, despite Brazil's stated commitment to multilateralism, in reality that commitment is thin and selective. Brazil has been reluctant to tie itself to regional institutions and has carefully avoided becoming the paymaster for collective public goods to the region. According to Gomes Saraiva (2010), Brazil views "integration as a way of gaining access to foreign markets, strengthening the country's bargaining position in international economic negotiations, and projecting Brazilian industry in the region" (p. 154). According to many observers, Brazil has been too self-interested and too focused on relative economic gains for it to be able to shoulder the responsibilities that go with true regional leadership. ${ }^{13}$ As was explained above, Brazil is a geopolitically satisfied country that wants to maximize its economic power but that does not seek regional political domination.

Curiously, the five components of a neo-mercantilist strategy identified by Huntington (1993) are also all present in Brazil's external economic policy strategy as practiced by the current Workers' Party-led government. They are all visible in the "National Champions" strategy, which aims to promote the international competitiveness and internationalization of Brazilian corporations. As AbuEl-Haj (2007) explains, Brazil has been building a neo-mercantilist development approach involving "noninstitutional restrictions on imports using exchange rates, regulation of financial flows, and active promotion of exports" (p. 109). When it comes to imports, Brazil is one of the most closed economies in the world (Canuto et al. 2015). At the same time, the government has invested in the internationalization of Brazilian corporations using subsidies channeled through the Brazil's state-run National Development Bank (BNDES) with the deliberate aim of gaining market shares (see Flynn 2007). Brazil has a sustained trade surplus with all countries in the South American region, save Bolivia, and it has been intervening heavily in currency markets, most prominently when it unilaterally decided to devalue its currency in 1999 in what practically amounted to a "beggar-thyneighbor" policy against the other Mercosur member states (see Krapohl et al. 2014). In discussing Brazil's neo-mercantilist strategy, Kröger (2012) shows how the main aim has been to gain international security and power by maximizing foreign exchange reserves.

Hegemonic geoeconomic strategies deploy economic power as a means to uphold regional leadership, without habitually resorting to coercion. As opposed to neoimperialist strategies, hegemonic strategies are characterized by a higher degree of self-restraint on the part of the regional power and "softer" forms of domination by way of cooperative institutional arrangements. ${ }^{14}$ It may involve the provision of private goods to neighboring states or regional public goods, on which other states in the

\footnotetext{
${ }^{13}$ For a discussion of Brazil's lack of regional leadership, see, e.g., Malamud and Rodriguez (2014).

${ }^{14}$ For a discussion of "restraint" as a necessary component of a hegemonic strategy, see Ikenberry (2001). See also Pedersen (2002) for his conceptualization of "cooperative hegemony."
} 
region will "free-ride" and take advantage of without sharing the costs (Gilpin 1987; Kindleberger 1986). A hegemonic geoeconomic strategy thus involves the regional power bearing a disproportional share of the costs for public goods (Prys 2010). Market-enhancing measures, including the provision of material benefits and rewards to subordinate states, such as trade facilitation, economic assistance, and giving access to the hegemon's market, all belong to the toolkit of hegemonic strategies. ${ }^{15}$

The European Union (EU) operates a quintessential geoeconomic hegemony strategy in its neighborhood. Without resorting to coercion, the EU uses its economic domination to uphold hegemony in relation to its periphery. An important motivation is to ensure the security of the continent. By relying on its formidable economic structure, the EU attempts to export its policies to its neighbors - either in the form of enlargement or through policies and programs such as PHARE, TACIS, and CARD that are designed to eventually bring the neighboring countries into the orbit of the EU (Le Gloannec 2011, p. 103). Le Gloannec explains that "The asymmetry between the European Union and the candidate countries allows the former to exclusively set the conditions. After all, it is the candidate country that suffers from exclusion, and it is the candidate country that seeks entry; economic dominance and power of attractionasymmetry in short - play into the hands of the EU-ropeans for one main reason, and that is, the professed desire of countries to join the EU..." (2011, p. 105). While the EU's relationship with its periphery is deeply asymmetrical, with neighboring economies dependent on the Union's internal market - so much so that Joffe (2007) speaks about a "hub and spoke" system in which the core dominates the periphery- the EU alone does not define this system. It is a result of an integration process through which neighboring countries can take part in re-defining the core and become part of it themselves. At the same time, it gives leaders of neighboring countries the chance to free-ride on EU support, enabling, for instance, the Belorussian government to take EU money while not adjusting to EU's policies (Le Gloannec 2011). As such, it forms a very different sort of geoeconomic strategy than that of neo-imperialism, which is less able than hegemony to rely on the power of attraction and less open to a process through which also the core becomes transformed.

Liberal institutionalist geoeconomic strategies are not deployed to pursue broader geopolitical goals but foremost to pursue economic objectives as such. They denote an economy-oriented notion of foreign policy idealism, as opposed to the realism of neomercantilism, building on the belief that extending interdependence and economic integration is a crucial imperative for all levels of security and prosperity. A liberal institutionalist geoeconomic power is essentially a "civilian power" that accepts the necessity of cooperation with others in the pursuit of national objectives but that displays an unwillingness of shouldering the broader burden and responsibility of being a "regional great power." Its national interest is defined foremost in economic terms, through the joint pursuit of economic stability and growth in a liberal multilateral setting.

Germany provides a case of such a liberal institutionalist geoeconomic strategy. Following World War II, West Germany dropped all pretensions for seeking hegemony in Europe. It was happy to emerge as what former chancellor Helmut Schmidt

\footnotetext{
${ }^{15}$ In a classic analysis, Keohane $(1984,45)$ explains how hegemony to a great part rests "on the subjective awareness by elites in secondary states that they are benefitting, as well as on the willingness of the hegemony itself to sacrifice tangible short-term benefits for intangible long-term gains."
} 
described as an economic giant but a political dwarf (cited in Szabo 2015, pp. 6-7). Germany's refusal to use its increasing economic power as a vehicle to develop its broader geopolitical power base, shying away from political and military leadership, precipitating talk about a "leadership avoidance complex" (see Miskimmon 2007, p. 24). Clearly, the German approach treated economic power as a goal in itself, not a means to broader geopolitical aims. For the West German identity, the economic miracle was its founding myth. It constituted, according to Müller (2005, pp. 144 145), "a modern equivalent to the Protestant ethic, which takes economic success as a sign of salvation." As for the strategic frame of Germany, it has clearly been cooperative, so much so that its foreign policy approach has been characterized as showing a reflexive support for an "exaggerated multilateralism" (Anderson 1999). While some observers see Germany's actions during the European crisis as testimony of a changing strategic frame towards a more competitive one, which would indicate a move from a liberal institutionalist to a neo-mercantilist geoeconomic strategy, at least up until the late 1990 s, Germany remained committed to a firm policy of self-binding and integration into European institutions (Anderson 1999; Kudnani 2011; Mayer 2010; Szabo 2015). Indeed, up until recently, as Miskimmon (2007, p. 35) reiterates, "Germany has seldom attempted to unilaterally affect the course of European integration."

Two qualifying remarks have to be made. Firstly, the distinctions between neoimperialist, neo-mercantilist, hegemonic, and liberal institutionalist geoeconomic strategies are ideal-typical in a Weberian sense (Table 1). It means that regional powers should not be expected to always follow a "pure" neo-imperialist, neo-mercantilist, hegemonic or liberal institutionalist strategy. As Destradi argues with reference to her own ideal-typical categories, they "act as a guideline for analysis, but what most probably will be identified in empirical research are situations in which a particular form of strategic orientation prevails." She continues that "since strategy is dynamic and subject to learning processes, [we]...should assume that regional powers can modify their strategies in the course of time, passing, for instance, from a [liberal institutionalist to a neo-mercantilist or from a hegemonic to a neo-imperialist strategy] in response to changed reactions by subordinate states, to domestic factors redefining state priorities, or to pressures deriving from the external environment, for example, from global powers" (Destradi 2010, p. 929). Secondly, the fact that different strategies may be used in different policy areas complicates matters, while it simultaneously opens up additional avenues for making within-case comparisons and testing for generalizability. For example, Russia's strategy may look different depending on whether the analysis looks at trade policy or energy policy. Empirical research should test for such possible variations. Notwithstanding, from the perspective of economic

Table 1 Tactics and policies of regional powers' geoeconomic strategies

\begin{tabular}{ll}
\hline Strategy & Tactics and policies \\
\hline Neo-imperialism & Economic force, coercion, imposition, and bribery \\
Hegemony & Provision of public and private goods \\
Neo-mercantilism & Protectionism and selective multilateralism \\
Liberal institutionalism & Economic integration and multilateralism \\
\hline
\end{tabular}


power, policy areas are of course of different importance and therefore not equally consequential. When evaluating geoeconomic strategies, one therefore needs to keep a close eye on what aspect of economic power is the most important for the particular regional power in question, e.g., energy in the case of Russia.

\section{Conclusion: implications for geoeconomic research}

Regional powers are increasingly important players in international politics. However, they are so mainly as economic actors, projecting their power through external economic policy. As a result, the concept of geoeconomics has become increasingly important in both policy debates and academic studies on foreign policy and international relations.

Yet, the geoeconomics research is still in its infancy. ${ }^{16}$ Not only is there great confusion over the concept of geoeconomics as such - indeed, it is often used without much critical reflection as to what is actually meant with it and few studies have attempted to explicitly define it - but no studies exist that would systematically compare the geoeconomic activities of regional powers. Assuming also that the ways in which these regional powers exercise their economic power have an influence on their neighbors and regional developments, the lacuna of research on regional powers' geoeconomics strategies is surprising.

The conceptual framework developed in this paper attempts to contribute to the incipient geoeconomic research in several regards. Firstly, by defining geoeconomics as the geostrategic use of economic power, it provides a much needed contribution to the debate on what geoeconomics actually is. This definition captures the essence of what most analysts refer to when speaking about geoeconomics as a foreign policy practice, while being broad enough to include both liberal and realist approaches. Currently, few attempts to define geoeconomics have been made and it has been used to denote everything from a neo-liberal governance discourse (Sparke 2007) to economic nationalist practices (Tsygankov 2005) as well as to describe shifting trends in international relations (Baracuhy 2013) or the notion that economic security concerns have eclipsed military security concerns in the post-Cold War era (Hsiung 2009). Such conceptual confusion exposes "geoeconomics" to the risk of becoming an empty signifier. That would be a shame since it clearly strikes a chord with some new trends in both foreign policy practice and international relations analysis. What is needed, therefore, is to add come clarity to the concept, and thus, more attempts to define it and make clear how the different elements usually associated with geoeconomics relate to each other are surely to be welcomed.

Secondly, the typology proposed in this paper provides for an analytically richer device for comparing regional powers and their strategies than existing theory, which assumes largely monolithic behavior among "geoeconomic powers." Currently, most geoeconomic analyses expect regional powers to engage in what has been called "commercial realism," closely related to what this paper has described as a neomercantilist strategy (e.g., Kudnani 2011; Szabo 2015; see also Huntington 1993). However, by reducing geoeconomic behavior to only denote neo-mercantilism, the question about geoeconomic strategy is resolved by definitional fiat. It overlooks how

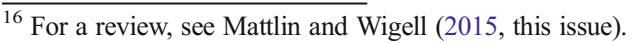


economic power may be geostrategically used as a means to achieve a variety of goals and through strategic frames other than an exclusively competitive one. Recently, more liberal understandings of geoeconomics have been put forward that emphasize these more cooperative dimensions. Indeed, reducing geoeconomics to commercial realism restricts our understanding of these other geostrategic uses of economic power. This paper therefore departs from a more eclectic approach to geoeconomics, which does not a priori exclude either realism or liberalism. Instead, by using the combinatorial logic of eclecticism, the paper constructs a typology that draws on the insights from both of them and is thereby able to expand the analytical contrast space to include a broader range of possible variation in geoeconomic strategy.

Thirdly, the ideal-typical taxonomy put forward here makes a useful distinction between neo-imperialism and hegemony, concepts that are sometimes conflated and have remained underspecified from a geoeconomics perspective. Here, a clear distinction is made between the two concepts, with the term hegemony referring to more benevolent leadership that includes the provision of collective goods, whereas neo-imperialism refers to a mala fide, unilateral pursuit of national interest by the dominant power, sustained, if necessary, by coercion, imposition or bribery, and the creation of dependent relations that limit the sovereignty of neighboring states. ${ }^{17}$ I explicitly use the term neo-imperialism to distinguish it from more traditional, geopolitical uses of the notion of empire, which center more exclusively around territorial annexation and control. Here, neo-imperialism is used to connect with the idea of an "informal empire" control and dependencies are used to reduce the effective sovereignty of neighboring states without any need for de facto territorial control.

Lastly, the typology constructed in this paper not only allows us to analytically grasp possible empirical variation in the geostrategic uses of economic power between regional powers but it may also provide for an important variable when attempting to explain different forms of regionalisms. If it is true that "the formative stage of regional institutionalization is best studied by focusing upon the strategy of the biggest state in a region" (Pedersen 2002, p. 696); then, being able to distinguish between different regional powers' geoeconomic strategies is an important step. As such, the conceptual framework suggested in this paper may serve as a possible basis not only for future geoeconomic research but also more broadly for research concerning regional relations, i.e., how a regional power's geoeconomic strategy shapes the regional order.

Open Access This article is distributed under the terms of the Creative Commons Attribution 4.0 International License (http://creativecommons.org/licenses/by/4.0/), which permits unrestricted use, distribution, and reproduction in any medium, provided you give appropriate credit to the original author(s) and the source, provide a link to the Creative Commons license, and indicate if changes were made.

\section{References}

Abu-El-Haj J (2007) From interdependence to neo-mercantilism: Brazilian capitalism in the age of globalization. Lat Am Perspect 34(5):92-114

Anderson J (1999) German unification and the union of Europe: the domestic politics of integration policy. Cambridge University Press, Cambridge

\footnotetext{
${ }^{17}$ See Destradi (2010) for a related discussion.

${ }^{18}$ For a discussion, see, e.g., Thompson (1992).
} 
Armijo LE, Mühlich L, Tirone DC (2014) The systemic financial importance of emerging powers. J Policy Model 36S:67-88

Baracuhy B (2013) Brazilian economic diplomacy: agriculture and the WTO. In: Bayne N, Woolcock S (eds) The new economic diplomacy: decision-making and negotiation in international economic relations. Ashgate Publishing, Aldershot, pp 341-357

Barnett M (1999) Culture, strategy and foreign policy change: Israel's road to Oslo. Eur J Int Relat 5(1):5-36

Baru S (2012) Geo-economics and strategy. Survival 54(3):47-58

Brattberg E, Hamilton DS (eds) (2014) Global flow security: a new security agenda for the transatlantic community in 2030. Center for Transatlantic Relations, Washington DC

Burges S (2012) Strategies and tactics for global change: democratic Brazil in comparative perspective. Glob Soc 26(3):351-368

Burges S (2013) Mistaking Brazil for a middle power. J Iber Lat Am Rese 19(2):286-302

Cable V (1995) What is international economic security? Int Aff 71(2):305-324

Canuto O, Fleischhaker C, Schellekens P (2015) The curious case of Brazil's closedness to trade, Vox CEPR's Policy Portal. http://www.voxeu.org/article/brazil-s-closedness-trade. Accessed 10 Feb 2015

Chen L, De Lombaerde P (2014) Testing the relationships between globalization, regionalization and the regional hubness of the BRICs. J Policy Model 36S:11-131

Cohen A (2009) Russia: the flawed energy superpower. In: Luft G, Korins A (eds) Energy security challenges for the 21st century: a reference handbook. ABC CLIO, Santa Barbara

Corrales J (2009) Using social power to balance soft power: Venezuela's foreign policy. Wash Q 32(4):97-114

Destradi S (2010) Regional powers and their strategies: empire, hegemony, and leadership. Rev Int Stud 36: 903-930

Flynn M (2007) Between subimperialism and globalization: a case study in the internationalization of Brazilian capital. Lat Am Perspect 34(6):9-27

Gilpin R (1987) The political economy of international relations. Princeton University Press, Princeton

Gomes Saraiva M (2010) Brazilian foreign policy towards South America during the Lula administration: caught between South America and Mercosur. Revista Brasileira de Polit Int 53:151-168

Grevi G (2011) Geo-economics and global governance. In: Martiningui A, Youngs R (eds) Challenges for European Foreign Policy in 2012: what kind of geo-economic Europe? FRIDE, Madrid

Grey S, Bergin T, Musaieva S, Anin R (2014) Special report: Putin's allies channelled billions to Ukraine oligarch, 26 November, Reuters

Grosse TG (2014) Geoeconomic relations between the EU and China: the lessons from the EU weapon embargo and from Galileo. Geopolitics 19(1):40-65

Hirschman AO (1980) National power and the structure of foreign trade. University of California Press, Berkeley

Hsiung JC (2009) The age of geoeconomics, China's global role, and prospects of cross-strait integration. J Chin Polit Sci 14:113-133

Huntington SP (1993) Why international primacy matters. Int Secur 17(4):68-83

Hurrell A (2006) Hegemony, liberalism and global order: what space for would-be great powers? Int Aff 82(1):1-19

Hurrell A (2013) The quest for autonomy: the evolution of Brazil's role in the international system, 19641985. FUNAG, Brasília

Ikenberry JG (2001) After victory: institutions, strategic restraint, and the rebuilding of order after major wars. Princeton University Press, Princeton

Jácome F (2011) Petrocaribe: the current phase of Venezuela's oil diplomacy in the Caribbean, policy paper 40, Friedrich Ebert Stiftung

Joffe GH (2007) The EU and the Mediterranean: open regionalism or peripheral dependence. In: Telo M (ed) European Union and new regionalism: regional actors and global governance in a post-hegemonic era, 2nd edn. Ashgate, Aldershot

Johnston AI (1995) Thinking about strategic culture. Int Secur 19(4):32-64

Kappel R (2011) On the economics of regional powers: theory and empirical results. In: Godehart N, Nabers D (eds) Regional powers and regional orders. Routledge, London

Keohane RO (1984) After hegemony: cooperation and discord in the world political economy. Princeton University Press, Princeton

Khandekar G (2014) Modi's foreign policy mantra: Geoeconomics, regional hegemony, global aspirations. Agora Asia-Europe 17. FRIDE, Madrid

Kindleberger CP (1986) The world in depression, 1929-1939. University of California Press, Berkeley

Knorr K (1977) International economic leverage and its uses. In: Knorr K, Trager FN (eds) Economic issues and national security. Regents Press of Kansas, Lawrence 
Krapohl S, Meissner KL, Muntschick J (2014) Regional powers as leaders or rambos? The ambivalent behaviour of Brazil and South Africa in regional economic integration. J Common Mark Stud 52(4):879-895

Kröger M (2012) Neomercantilist capitalism and post-2008 cleavages in economic decision-making power in Brazil. Third World Q 33(5):887-901

Kudnani H (2011) Germany as a geo-economic power. Wash Q 34(3):31-45

Le Gloannec A-M (2011) The European Union as a regional power. In: Godehart N, Nabers D (eds) Regional powers and regional orders. Routledge, London

Liuhto K (2010) Energy in Russia's foreign policy, electronic publications of Pan-European Institute 10/2010

Luttwak EN (1990) From geopolitics to geo-economics: logic of conflict, grammar of commerce. Natl Interest 20:17-24

Malamud A, Rodriquez JCC (2014) Straddling the region and the world: Brazil's dual foreign policy comes of age. In: Herzog M, Robins P (eds) The role, position and agency of cusp states in international relations. Routledge, London

Mattlin M, Wigell M (2015) In search of the elusive meaning of geoeconomics, Asia-Europe Journal, this issue

Mayer H (2010) France, Germany, UK: responses of traditional to rising regional powers. In: Flemes D (ed) Regional leadership in the global system: ideas, interests and strategies of regional powers. Ashgate, Farnham

McKeown TJ (1983) Hegemonic stability theory and the 19th century tariff levels in Europe. Int Organ 37(1): 73-91

Mearsheimer JJ (2001) The tragedy of great power politics. Norton, New York

Miskimmon A (2007) Germany and the common foreign and security policy of the European Union: between Europeanisation and national adaptation. Palgrave Macmillan, Basingstoke

Mudiam PR (2007) Indian power projection in the greater Middle East: tools and objectives. Perspect Global Dev Tech 6:417-439

Müller K (2005) Nationalist undercurrents in German economic liberalism. In: Helleiner E, Pickel A (eds) Economic nationalism in a globalizing world. Cornell University Press, New York

Nolte D (2010) How to compare regional powers: analytical concepts and research topics. Rev Int Stud 36(4): 881-901

Paul A (2013) Beyond Vilnius: Keeping the Eastern partnership on track, Commentary, European Policy Centre. http://www.epc.eu/documents/uploads/pub_3791_beyond_vilnius_-_keeping_the_eastern parternship on track.pdf. Accessed 11 December $201 \overline{4}$

Pedersen T (2002) Cooperative hegemony: power, ideas and institutions in regional integration. Rev Int Stud 28:677-696

Prys M (2010) Hegemony, domination, detachment: differences in regional powerhood. Int Stud Rev 12:479504

Prys M (2012) Redefining regional power in international relations: Indian and South African perspectives. Routledge, London

Roberts S, Marin A, Moshes A, Pynnöniemi K (2014) The Eurasian Economic Union: breaking the pattern of post-society integration? FIIA analysis 3, the Finnish Institute of International Affairs, Helsinki

Rosecrance R (1986) The rise of the trading state: commerce and conquest in the modern world. Basic Books, New York

Sil R, Katzenstein PJ (2010) Analytic eclecticism in the study of world politics: reconfiguring problems and mechanisms across research traditions. Perspect Polit 8(2):411-431

Soares de Lima MR, Hirst M (2006) Brazil as an intermediate state and regional power: action, choice and responsibilities. Int Aff 82(1):21-40

Sparke M (2007) Geopolitical fears, geoeconomic hopes, and the responsibilities of geography. Ann Assoc Am Geogr 97(2):338-349

Stulberg AN (2005) Moving beyond the Great Game: The geoeconomics of Russia's influence in the Caspian energy bonanza. Geopolitics 10(1):1-25

Szabo SF (2015) Germany, Russia, and the rise of geo-economics. Bloomsbury, London

Thompson A (1992) Informal empire? An exploration in the history of Anglo-Argentine relations, 1810-1914. J Lat Am Stud 24(2):419-436

Tsygankov AJ (2005) The return to Eurasia: Russia's identity and geoeconomic choices in the post-Soviet world. In: Helleiner E, Pickel A (eds) Economic nationalism in a globalizing world. Cornell University Press, New York

Wall S (2008) A stranger in Europe: Britain and the EU from Thatcher to Blair. Oxford University Press, Oxford 
Wright T (2013) Sifting through interdependence. Wash Q 36(4):7-23

Wu F, Koh DW (2014) From financial assets to financial statecraft: the case of China and emerging economies of Africa and Latin America. J Contemp China 23(89):781-803

Zarate J (2012) Playing a new geoeconomic game. In: Cohen C, Gabel J (eds) 2012 Global forecast: risk, opportunity and the next administration. Center for Strategic and International Studies, Washington, DC 